\title{
Denominational Research Report: Attitudes of Taiwan Catholics Toward Sexual Ethics
}

\author{
Chieh-Ju Chen
}

Published online: 21 September 2011

(C) The Author(s) 2011. This article is published with open access at Springerlink.com

\section{Study and Sample}

The factors influencing attitudes of Taiwan Catholics regarding sexual ethics were investigated by a survey. The number of Roman Catholics in Taiwan was estimated at 230,000 by the Roman Catholic Church in 2009. Of this total, about half are aboriginal Taiwanese, scattered through seven dioceses. The survey was sent to 405 persons in these seven dioceses, based on a .0017 ratio of the Catholic population from each diocese. Of the 390 surveys returned, 349 completed the full survey for this analysis.

\section{Variables and Hypotheses}

Sexual ethics, the dependent variable, comprised attitudinal questions on norms of conduct on premarital sex, adultery, birth control, abortion, homosexuality and divorce. The higher the score on this index of sexual ethics, the higher the conformity to Church sexual teachings. The three independent variable clusters were: Church norms, or sexual norms of conduct preached by the Church; family upbringing, including parental teaching, guidance, and attitudes on sexual issues; and media reports, or views on sexual ethics as reflected by the audio/visual and print press media. The research sought to test two major null hypotheses. (1) There is no difference between the model covariance matrix and the sample covariance matrix in showing no significant effect of family upbringing, the media reports or

\section{C.-J. Chen}

Graduate School of Human Sexuality, Shu-Te University, Kaohsiung, Taiwan, ROC

C.-J. Chen $(\bowtie)$

187-50, Sec. 2, Jianguo Road, Minshiung Shiang, Chiai 62153, Taiwan, ROC

e-mail: cgertrude@gmail.com; chiehjgc@yahoo.com 
Church norms on sexual ethics. (2) Population and background factors that include gender, age, cultural heritage, marital status, length of church membership and educational level, have no significant effect on sexual ethics. This study used Structural Equation Modeling (SEM) for data analysis and model review.

\section{Results}

Structural model coefficient analysis revealed that Church norms and family upbringing were significantly related to sexual ethics; supporting our hypothesis regarding these two variable clusters. Since there was no significant relationship between media reports and sexual ethics, our hypothesis regarding media reports was not supported. Further, the results did not support our hypotheses that gender, age or marital status have a significant effect on attitudes toward sexual ethics. Attitudes toward sexual ethics do, however, show significant differences based on cultural heritage status, length of church membership and education, suggesting that these hypotheses are valid.

Open Access This article is distributed under the terms of the Creative Commons Attribution Noncommercial License which permits any noncommercial use, distribution, and reproduction in any medium, provided the original author(s) and source are credited. 